\title{
Alica KřÁPKOVÁ, Brünn \\ Sexual Offences in Czech Town Books from the Early Modern Period
}

The study deals with sexual offenses in the written sources of the Late Middle Ages and the Early Modern Age in the present Czech Republic and Slovakia. It evaluates which actions fall into this category and defines their content under current criminal law. Similarly, it deals with punishments. Then it analyzes specific sources and evaluates the proportion of these deeds compared to other crimes. It provides a view of the society and the functioning of the law.

Keywords: court records - Early Modern Period - Late Middle Ages - punishments - sexual crimes

The broader issue is rather extensive and complicated for a complex elaboration; thus my contribution focuses only on a selected aspect. In addition to a general theoretical overview of the acts that were considered criminal during the feudal period and also punished with a whole range of sentences, I set out to analyse selected town books and their summary of the factuality as to how these offences were punished, or how often the municipal courts had to deal with them. Next, I try to explain the basic concepts related to this group of crimes which can be found in the historical time records. The methodology consisted in the selection of appropriate legal sources, editions and other specialized literature, and an analysis of available resources. I have chosen the probe method and applied it to selected town books, court records and black books from the territories of Bohemia, Moravia and also Slovakia (for comparison) from the period between the 14th and the 18th centuries. I excluded town books from major centres such as Prague, Brno or Bratislava because these cities did not fit in the selected sample as the specific problem of the period was characteristic. Of course, town books that did not deal with criminal law were also excluded, such as directive books, books of writing debts, inheritances and commitments.

The understanding of moral offences in town law has gone through long-term developments. Some of them are known from Roman law. In our countries, the law began to be implemented from the 11th century, in the law record known as Brretislav's decree that dates back to the year 1039. ${ }^{1}$ In the Slovak territory, it was the Zakon sudnyj ljudem from 863-869.2 The main stimulus for their implementation were the measures of the church, which sought to remove pagan customs from society and focused its attention especially on the areas of marriage and sexual life. They forbid bigamy, fornication, adultery but also the birth of illegitimate children. ${ }^{3}$ The punishment for these deeds was exile from the country. ${ }^{4}$ For a long time, the church was the one who decided about these actions, until it gradually passed this competence on to the municipal courts as well.

\footnotetext{
${ }^{1}$ VOJÁČEK, SCHELLE, KNOLL, České právní dějiny 123.

2 LAClAVíKOVÁ, Švecová, Pramene práva na území Slovenska. I., 49.

${ }^{3}$ FRANCEK, Velké dějiny zemí Koruny české 218.

${ }^{4}$ BlÁHOVÁ, Hrdina, Kosmova kronika česká 81.
} 
Initially, there is considerable fragmentation and inconsistency in town law. It originated under the influence of German merchants coming to our territory and our ancestors accepting their habits and customs. Thus, it consists of two basic legal families, the law of North Germany, namely Magdeburg, and South Germany, namely Nuremberg. ${ }^{5}$ However, these legal bases underwent a gradual development and each city to which the laws were granted transformed them over time according to their own needs and customs. The earliest legal documents of these laws are town books, which may either contain a direct register of legal norms and regulations or may also contain entries of disputes and their resolutions in the territory of the city. Town law in the area now covered by the Czech Republic was unified by the so-called Koldin Code, which is one of the most important sources of town law. Another type of documents, especially in the criminal law area, are the so-called executions or black books written by town scribes as evidence of the questioning of the accused under torture.

Which acts were therefore regarded as sexual or moral delinquency in town law? They included adultery (adulterium), a violation of the marital sexual life with another man or woman outside marriage. The act of bigamy (double marriage) is also related to adultery. Another was fornication, a voluntary sexual act with a person of the opposite sex outside marriage, in the case of a woman with a virgin or a widow. Additionally, there is also non-marital coexistence, typical of the less wealthy layers of society, called the concubinage. Another offence was rape (stuprum), which is the involuntary and enforced sexual intercourse with a woman, regardless of whether the woman was married or not. Similarly, child abuse or abuse of a minor belongs here. Following is incest (incestum), which is sexual

\footnotetext{
${ }^{5}$ FRANCEK, Zločin a trest 25-26.
}

activity between relatives, usually between siblings or parents and offspring, either as a voluntary or involuntary act. Another is sodomy, which includes several different facts, primarily referring to the sexual intercourse of men with animals. In addition, there is homosexuality, or sex among members of the same sex, or other non-traditional or unauthorized sexual practices. The last of the moral crimes was prostitution and related offences such as profiting from prostitution.

Indirectly, the murder of a newborn (infancidium) and abortion (abortio) could be added to these moral offences. Pregnancy is also connected with these but is far more often sanctioned in relation to some of the above-mentioned facts. In some sources, the offence of kidnapping or honour offence, which was usually associated with adultery or rape, also belonged to moral delinquencies.

So how did the substantiation of these deeds work in court? The easiest way was to catch the offender or offenders in the act, calling of more witnesses followed, possibly court officers or a reeve. Another way was the witness oath. The number of required witnesses was different for individual deeds. For example, in the Code of Town and Mining Law of Banská Štiavnica, § 24 reads:

"If a girl of woman sues that she has been abused in a field, one witness is enough, it may be a shepherd or any other man. In the city, two witnesses are enough. If a girl or woman with a torn dress and dishevelled hair, bloodied or not, complains and has no witnesses, the one being sued can defend himself with two witnesses. If the one suing has an intact dress and is not bloodied, the accused can defend himself." 6

\footnotetext{
${ }^{6}$ Translation by the author, original text in Slovak language: "Ak dievča, alebo žena žaluje, že bola zneužitá v poli, stačí jej jeden svedok, môže to byt’ pastier, alebo hociktorý iný muž. V meste jej stačia dvaja svedkovia. Ak sa stažuje dievča alebo žena
} 
Another way was examination - typical of rape, which can be exemplified by the enactment in the Koldin Code: "If the office has information that a virgin had been violated, they may let honest women examine her in private." 7 The last way was the confession under torture, which is the content of the black books. For example, the black book of the city of Kutná Hora records the exact process of procuring a statement, either voluntary or "after suffering", and often the specific methods of torture, for example on a ladder or rack. The type of punishment varied at the discretion of the judges; in general, records included the death penalty for adultery, rape, bigamy, possibly in combination with other crimes, theft or murder. Punishment by drowning or hanging was also possible. An interesting case happened in Kutná Hora, where the accused Šebestyán Rosa of Domažlice was hanged after committing theft, adultery, four rapes and having dressed in women's clothes for three years, for which he had been exiled from his native village Domažlice. ${ }^{8}$ An interesting and unconventional punishment from a present day perspective was that marriage was considered in the case of rape, if the victim agreed. Only the women were punished by drowning or burying alive, the punishment most commonly given for fornication, abortion or murder of a newborn, often aggravated by impaling. Less cruel punishments were being exiled from the town, beating at the pillory or branding, usually for fornication, adultery or prostitution.

The second part of this paper focuses on assessing the town justice probe. Selected legal

s roztrhanými šatami a strapatými vlasmi, skrvavená alebo nie a nemá svedkov, môže sa ten, na koho žaluje obhájit pomocou dvoch svedkov. Ak má žalujúca neporušený odev, nie je skrvavená, môže sa obvinený obhájit' sám." VOZÁR, Kódex 43.

7 Translation by author, original text in Czech language: „Ouřad, maje správu, že by některá panna $\mathrm{k}$ porušení přišla, muže ji dáti ženám poctivým v soukromí ohledati.“ MALÝ, Práva městská 557.

${ }^{8}$ Bisingerová et al., Kutnohorský manuál 17-18. sources are ranked from the oldest to the youngest, regardless of the type of entry and type of document. In each case, the provisions on the offence in question were identified, to which the type of record is assigned, whether it is a normative record or a record of the court proceedings. If possible, the number of record and date is also assigned. Finally, the penalty is recorded if one was pronounced. All the data is clearly projected into a table and subsequently evaluated in a graph - of course only in the case of court proceedings. Only books containing court records provide the most important insights into the court practice of the medieval towns and show the spectrum of sexual offences.

- Town Book of Litoměřice (CZ) 1341-1562

- The oldest Town Book of Olomouc (CZ) 13431420

- Law Book of Míšeň (CZ) 1357/8-1387

- Town Book of Žilina (SK) 1379-1561

- Black Book of Kutná Hora (CZ) 1521-1571

- Code of Town and Mining Law of Banská Štiavnica (SK) 1572

- Black Book of Velká Bíteš (CZ) 1556-1636

- Black Book of Rokycany (CZ) 1573-1630

- Town Laws of the Kingdom of Bohemia and Margraviate of Moravia, so called Koldín's Code (CZ) 1579

- Black Book of Lipník (CZ) 1594-1627

- Black Book of Smidary (CZ) 1631-1769

Among the so-called law books are the Mišeňská book, the Code of Town and Mining Law of Banská Štiavnica and so-called mixed books, containing both normative records and records of court proceedings, Žilinská book and Litoměřická book. The Koldin Code also is part of this group, even though it is not a town book but a codification of town law. For this reason, it was selected for this work. In the second group are books recording the court proceedings and so-called black books. The analysis of the town books is sorted by the age of the books, not by the type. 


\section{Town Book of Litoměřice 1341-1562 ${ }^{9}$}

One of the so-called mixed books, it contains 58 records and deals with unwanted sexual behaviour in only one provision. It is a regulation of the city council about women's manners.

\begin{tabular}{|l|l|l|l|l|}
\hline $\begin{array}{l}\text { Criminal } \\
\text { offence }\end{array}$ & $\begin{array}{l}\text { Type of } \\
\text { record }\end{array}$ & No. $^{10}$ & Date & Punishment \\
\hline nodultery & normative & 24 & 5.2 .1441 & W $^{11}:$ expulsion from the town \\
\hline fornication & normative & 24 & 5.2 .1441 & $\begin{array}{l}\text { W: financial fine } \\
\text { M: loss of throat by sword }\end{array}$ \\
\hline prostitution & normative & 24 & 5.2 .1441 & W: expulsion from the town, whipping \\
\hline
\end{tabular}

\section{The oldest Town Book of Olomouc 1343-142012}

The town book from the city of Olomouc includes records of private as well as criminal law. Some entries have a commemorative character. Most of records are brief and rather informative. They often do not contain a punishment and only describe the event.

\begin{tabular}{|l|l|l|l|l|}
\hline $\begin{array}{l}\text { Criminal } \\
\text { offence }\end{array}$ & $\begin{array}{l}\text { Type of } \\
\text { record }\end{array}$ & No. & Date & Punishment \\
\hline concubinage & court record & 58 & 1353 & - \\
\hline soliciting & court record & 58 & 1353 & - \\
\hline rape & court record & 145 & 1359 & - \\
\hline fornication & court record & 240 & 1370 & exile for 100 and 1 years \\
\hline kidnap & court record & 643 & 1384 & - \\
\hline rape & court record & 643 & 1384 & prison, loss of throat \\
\hline
\end{tabular}

Total number of entries: 729

Number of entries about sexual offences: 4

\footnotetext{
${ }^{9}$ Edition used: KOCÁNOVÁ, TOMAS, Městská kniha Litoměřic.

${ }^{10}$ Understand the entry number.

${ }^{11} \mathrm{~W}$ = punishment for women; $\mathrm{M}$ = punishment for men.

${ }^{12}$ Edition used: SPÁČIL, Nejstarší městská kniha olomoucká.
} 


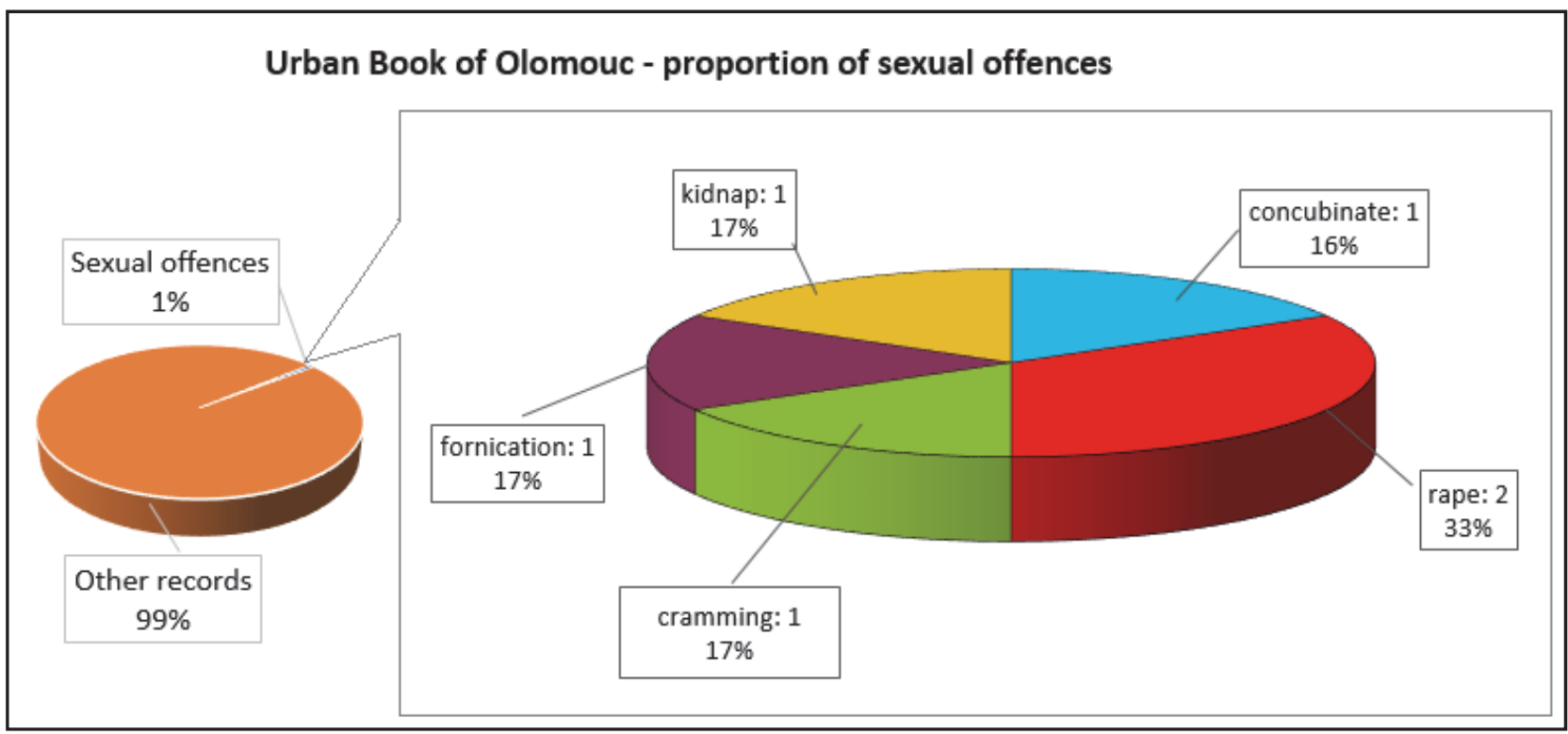

\section{Law Book of Meißen 1357/8-138713}

The law book of the normative type used in Olomouc. It was based on Magdeburg's town law. In some cases, provisions only define a sexual offence in terms of the facts, for other offences they determine a specific punishment.

\begin{tabular}{|l|l|l|l|l|}
\hline $\begin{array}{l}\text { Criminal } \\
\text { offence }\end{array}$ & $\begin{array}{l}\text { Type of } \\
\text { record }\end{array}$ & No. & Date & Punishment \\
\hline rape & normative & I.13.3 & - & - \\
\hline rape & normative & IV.8.1,3,4,5,6 & - & loss of throat by sword \\
\hline kidnap & normative & IV.8.1,3,4,6 & - & remission \\
\hline fornication & normative & IV.8.2 & - & - \\
\hline $\begin{array}{l}\text { offence of honour } \\
\text { (rape of wife) }\end{array}$ & normative & IV.9.1 & - & - \\
\hline adultery & normative & IV.9.2 & - & $\begin{array}{l}\text { husband can kill both, otherwise exe- } \\
\text { cuted }\end{array}$ \\
\hline child abuse & normative & IV.9.4 & - & loss of throat by sword \\
\hline fornication & normative & IV.11.6 & - & W: burial alive \\
\hline
\end{tabular}

\footnotetext{
${ }^{13}$ Edition used: SPÁČIL, SPÁČILOVÁ, Míšeňská právní kniha.
} 


\section{Law Book of Žilina 1378-15614}

The law book of Žilina is another example of a mixed book; it contains 368 normative provisions from the translation (from the year 1473) of an original version written in the German language (from the year 1378). It originally contained 432 provisions of town and feudatory law. The second part consists of 72 court records. The normative part, as was the case with the Meißen book, came from Magdeburg's family of law.

\begin{tabular}{|l|l|l|l|l|}
\hline $\begin{array}{l}\text { Criminal } \\
\text { offence }\end{array}$ & $\begin{array}{l}\text { Type of } \\
\text { record }\end{array}$ & No. & Date & Punishment \\
\hline rape & normative & $\S 7$ & - & loss of throat \\
\hline fornication & normative & $\S 352$ & - & marriage \\
\hline adultery & normative & $\S 352$ & - & fight \\
\hline rape & normative & $\S 365$ & - & - \\
\hline $\begin{array}{l}\text { fornication/ } \\
\text { adultery }\end{array}$ & court record & 59 & 13.7 .1460 & - \\
\hline rape & court record & 59 & 13.7 .1460 & - \\
\hline
\end{tabular}

Total number of entries (court): 72

Number of entries about sexual crimes: 1

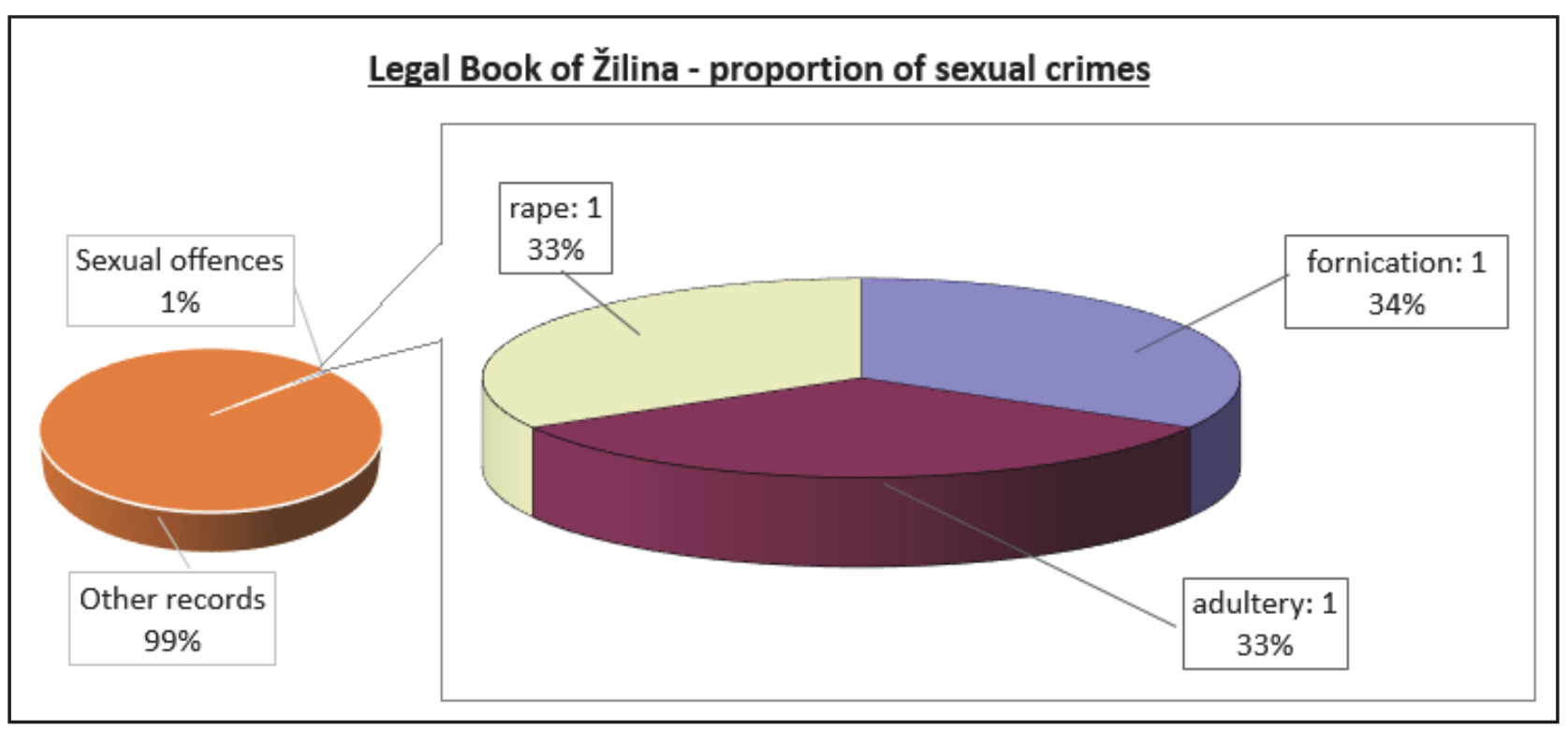

\footnotetext{
${ }^{14}$ Edition used: Rudolf KUCHAR, Žilinská právna kniha, and PAPSONOVÁ, Sasko-magdeburské právo na Slovensku.
} 


\section{Black Book of Kutná Hora 1521-1571 ${ }^{15}$}

The black book contains reports from hearings under torture. They usually indicate the date, name of the investigated person, the facts or actions he/she has committed, the type of hearing and the judgment.

\begin{tabular}{|c|c|c|c|c|}
\hline $\begin{array}{l}\text { Criminal } \\
\text { offence }\end{array}$ & $\begin{array}{l}\text { Type of } \\
\text { record }\end{array}$ & No. & Date & Punishment \\
\hline rape & court record & 3 & 30.4 .1522 & loss of throat by sword \\
\hline adultery & court record & 15 & 22.4 .1524 & exile from the town \\
\hline fornication & court record & 17 & 29.7.1524 & $\begin{array}{l}\text { exile from the town within a radius of four } \\
\text { miles }\end{array}$ \\
\hline rape etc. & court record & 36 & 23.2.1525 & woven onto the wheel \\
\hline fornication etc. & court record & 47 & 9.2 .1526 & death by hanging (for murder) \\
\hline $\begin{array}{l}\text { murder of a } \\
\text { newborn }\end{array}$ & court record & 54 & - & - \\
\hline $\begin{array}{l}\text { murder of a } \\
\text { newborn }\end{array}$ & court record & 74 & burial alive & burial alive \\
\hline bigamy & court record & 87 & 16.10.1553 & $\begin{array}{l}\text { exile from the town, if they came back, loss } \\
\text { of throat }\end{array}$ \\
\hline fornication etc. & court record & 91 & 13.1.1554 & death by hanging (for thefts) \\
\hline $\begin{array}{l}\text { murder of a } \\
\text { newborn }\end{array}$ & court record & 97 & 27.6.1554 & $\begin{array}{l}\text { burial alive and puncture of the heart by } \\
\text { stick }\end{array}$ \\
\hline $\begin{array}{l}\text { murder of a } \\
\text { newborn }\end{array}$ & court record & 101 & 15.10 .1554 & burial alive \\
\hline adultery & court record & 107 & 26.6.1555 & exile from the town \\
\hline $\begin{array}{l}\text { murder of a } \\
\text { newborn }\end{array}$ & court record & 108 & 29.7.1555 & $\begin{array}{l}\text { burial alive and puncture of the heart by } \\
\text { stick }\end{array}$ \\
\hline abortions & court record & 108 & 29.7.1555 & $\begin{array}{l}\text { burial alive and puncture of the heart by } \\
\text { stick }\end{array}$ \\
\hline fornication & court record & 121 & 20.1.1556 & exile from the town \\
\hline rape & court record & 123 & 6.7 .1556 & loss of throat by sword \\
\hline adultery & court record & 126 & 18.3.1556 & exile from the town, before pillory \\
\hline bigamy & court record & 127 & 21.6.1556 & $\begin{array}{l}\text { exile from the town and before whipping } \\
\text { at the pillory }\end{array}$ \\
\hline
\end{tabular}

${ }^{15}$ Edition used: BISINGEROVÁ, Kutnohorský manuál. 


\begin{tabular}{|c|c|c|c|c|}
\hline fornication & court record & 128 & 3.6.1556 & exile from the town \\
\hline adultery & court record & 131 & 5.8 .1556 & $\begin{array}{l}\text { exile from the town, if they came back, } \\
\text { whipping at the pillory }\end{array}$ \\
\hline fornication & court record & 132 & 5.8 .1556 & $\begin{array}{l}\text { exile from the town, if they came back, } \\
\text { whipping at the pillory }\end{array}$ \\
\hline bigamy & court record & 134 & 23.3.1557 & loss of throat by sword \\
\hline fornication & court record & 135 & 5.7.1557 & $\begin{array}{l}\text { exile from the town, if they came back, } \\
\text { whipping at the pillory and two brands }\end{array}$ \\
\hline fornication & court record & 143 & 25.10 .1557 & exile from the town \\
\hline fornication & court record & 146 & 29.11.1557 & pillory, but finally remission \\
\hline fornication & court record & 147 & 29.11.1557 & exile from the town \\
\hline fornication & court record & 148 & 29.11.1557 & exile from the town \\
\hline fornication & court record & 149 & 29.11.1557 & exile from the town \\
\hline fornication & court record & 156 & 5.12 .1558 & exile from the town \\
\hline $\begin{array}{l}\text { murder of a new- } \\
\text { born }\end{array}$ & court record & 168 & 9.6 .1559 & $\begin{array}{l}\text { burial alive and puncture of the heart by } \\
\text { stick }\end{array}$ \\
\hline concubinage & court record & 178 & 24.6.1560 & exile from the town \\
\hline fornication & court record & 179 & 15.1.1560 & $\begin{array}{l}\text { exile from the town, if they came back, } \\
\text { pillory }\end{array}$ \\
\hline fornication & court record & 180 & 29.1.1560 & $\begin{array}{l}\text { exile from the town, if they came back, } \\
\text { pillory }\end{array}$ \\
\hline $\begin{array}{l}\text { fornication and } \\
\text { murder of a } \\
\text { newborn }\end{array}$ & court record & 182 & 9.10 .1560 & $\begin{array}{l}\text { burial alive and puncture of the heart by } \\
\text { stick }\end{array}$ \\
\hline adultery & court record & 183 & 28.10 .1560 & whipping at the pillory \\
\hline fornication & court record & 184 & 8.11 .1560 & $\begin{array}{l}\text { exile from the town, if they came back, } \\
\text { whipping at the pillory }\end{array}$ \\
\hline fornication & court record & 192 & 21.4.1561 & exile from the town \\
\hline rape etc. & court record & 193 & 28.4 .1561 & woven onto the wheel (for murder) \\
\hline pregnancy & court record & 195 & 28.5.1561 & exile from the town \\
\hline pregnancy & court record & 196 & 28.5.1561 & exile from the town \\
\hline
\end{tabular}




\begin{tabular}{|c|c|c|c|c|}
\hline $\begin{array}{l}\text { murder of a } \\
\text { newborn }\end{array}$ & court record & 209 & 1.2 .1563 & $\begin{array}{l}\text { burial alive and puncture of the heart by } \\
\text { stick }\end{array}$ \\
\hline pregnancy & court record & 214 & 31.1 .1563 & $\begin{array}{l}\text { whipping at the pillory and exile from the } \\
\text { town }\end{array}$ \\
\hline pregnancy & court record & 216 & 10.2 .1563 & $\begin{array}{l}\text { whipping at the pillory and exile from the } \\
\text { town }\end{array}$ \\
\hline bigamy & court record & 226 & 8.9 .1563 & loss of throat by sword \\
\hline fornication & court record & 227 & 1559 & $\begin{array}{l}\text { whipping at the pillory and exile from the } \\
\text { town }\end{array}$ \\
\hline fornication & court record & 232 & 29.5.1564 & exile from the town \\
\hline bigamy & court record & 233 & 19.6.1564 & $\begin{array}{l}\text { whipping at the pillory, two brands and } \\
\text { exile from the town }\end{array}$ \\
\hline bigamy & court record & 241 & 5.9.1564 & whipping at the pillory \\
\hline bigamy & court record & 244 & 13.11.1564 & $\begin{array}{l}\text { whipping at the pillory and exile from the } \\
\text { town }\end{array}$ \\
\hline fornication & court record & 248 & 14.3 .1565 & exile from the town \\
\hline fornication & court record & 254 & 3.7.1565 & exile from the town \\
\hline bigamy & court record & 258 & 29.10 .1565 & $\begin{array}{l}\text { exile from the town within radius of four } \\
\text { miles, otherwise death penalty }\end{array}$ \\
\hline prostitution & court record & 263 & 14.1 .1566 & $\begin{array}{l}\text { exile from the town, after she came back, } \\
\text { whipping at the pillory }\end{array}$ \\
\hline fornication & court record & 266 & 28.11.1565 & exile from town \\
\hline adultery & court record & 267 & 4.2 .1566 & whipping at the pillory \\
\hline adultery & court record & 268 & 4.2 .1566 & $\begin{array}{l}\text { whipping at the pillory and exile from the } \\
\text { town }\end{array}$ \\
\hline adultery & court record & 269 & 4.2 .1566 & $\begin{array}{l}\text { whipping at the pillory and exile from the } \\
\text { town }\end{array}$ \\
\hline adultery & court record & 270 & 23.1 .1566 & death by hanging (for thefts) \\
\hline pregnancy & court record & 278 & 1.4 .1566 & $\begin{array}{l}\text { burial alive and puncture of the heart by } \\
\text { stick (plus other crimes) }\end{array}$ \\
\hline adultery & court record & 293 & 28.4 .1567 & death by hanging (for thefts) \\
\hline rape & court record & 293 & 28.4 .1567 & see above \\
\hline $\begin{array}{l}\text { walking in wom- } \\
\text { en's dress (sodo- } \\
\text { my) }\end{array}$ & court record & 293 & 28.4.1567 & see above \\
\hline
\end{tabular}




\begin{tabular}{|c|c|c|c|c|}
\hline bigamy & court record & 306 & 11.8.1567 & $\begin{array}{l}\text { exile from the town within radius of four } \\
\text { miles }\end{array}$ \\
\hline $\begin{array}{l}\text { adultery and big- } \\
\text { amy }\end{array}$ & court record & 312 & 9.1.1568 & $\begin{array}{l}\text { exile from the town within radius of four } \\
\text { miles, otherwise death penalty }\end{array}$ \\
\hline sodomy & court record & 315 & 24.5.1568 & $\begin{array}{l}\text { whipping at the pillory, two brands, exile } \\
\text { from the town, otherwise death penalty }\end{array}$ \\
\hline prostitution & court record & 319 & 7.7.1568 & exile from the town ( $2^{\text {nd }}$ time $)$ \\
\hline fornication etc. & court record & 320 & 13.10.1568 & $\begin{array}{l}\text { exile from the town within radius of four } \\
\text { miles, otherwise death penalty }\end{array}$ \\
\hline fornication & court record & 323 & 15.10 .1568 & $\begin{array}{l}\text { exile from the town, otherwise death pen- } \\
\text { alty }\end{array}$ \\
\hline bigamy & court record & 324 & 25.10 .1568 & $\begin{array}{l}\text { whipping at the pillory, exile from the } \\
\text { town, otherwise death penalty }\end{array}$ \\
\hline fornication & court record & 334 & 10.6.1569 & exile from the town, bring out to gallows \\
\hline pregnancy & court record & 340 & 12.9.1569 & $\begin{array}{l}\text { exile from the town, otherwise death pen- } \\
\text { alty }\end{array}$ \\
\hline pregnancy & court record & 341 & 5.10 .1569 & $\begin{array}{l}\text { whipping at the pillory, exile from the } \\
\text { town }\end{array}$ \\
\hline rape etc. & court record & 343 & 16.11.1569 & $\begin{array}{l}\text { death - torn with tongs, breaking by a } \\
\text { wheel, quartering (for murder etc.) }\end{array}$ \\
\hline fornication & court record & 358 & 5.7.1570 & loss of throat by sword \\
\hline adultery & court record & 360 & 2.10 .1570 & loss of throat by sword \\
\hline concubinage etc. & court record & 372 & 7.3.1571 & death by wheel \\
\hline $\begin{array}{l}\text { murder of a } \\
\text { newborn }\end{array}$ & court record & 373 & 6.4.1571 & $\begin{array}{l}\text { burial alive and puncture of the heart by } \\
\text { stick }\end{array}$ \\
\hline
\end{tabular}

Total number of entries: 382

Number of entries about sexual offences: 74 


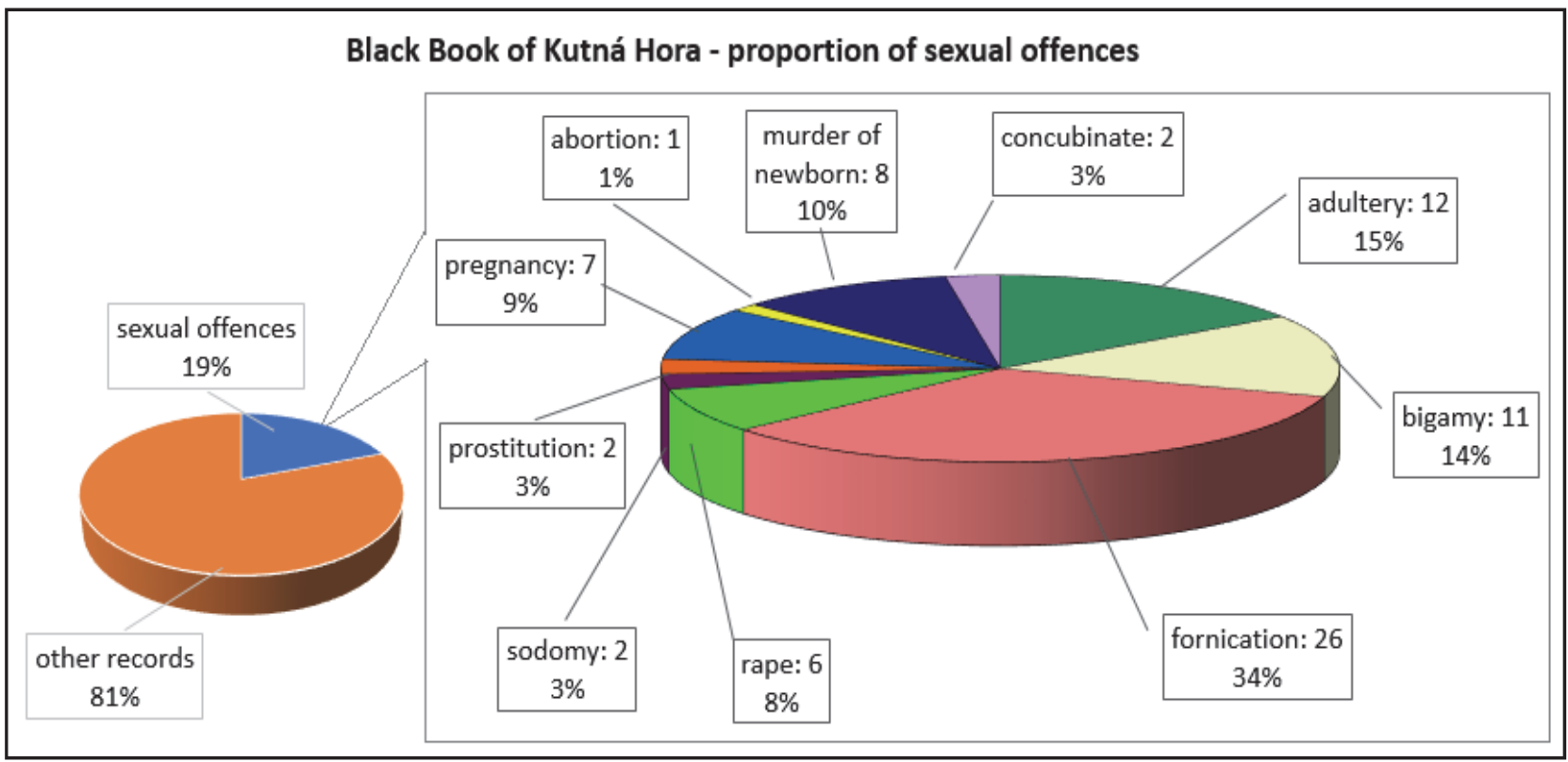

\section{Code of Town and Mining Law of Banská Štiavnica $1572^{16}$}

The law book of the mining city Banská Štiavnica consists of two parts. The first one is relevant to town law and contains 41 provisions. The second one deals with mining law and is not very relevant for this topic.

\begin{tabular}{|l|l|l|l|l|}
\hline $\begin{array}{l}\text { Criminal } \\
\text { offence }\end{array}$ & $\begin{array}{l}\text { Type of } \\
\text { record }\end{array}$ & No. & Date & Punishment \\
\hline rape & Normative & $\S 24$ & - & loss of throat by sword \\
\hline kidnap & Normative & $\S 27$ & - & loss of throat by sword \\
\hline
\end{tabular}

\section{Black Book of Velká Bíteš 1556-1636 ${ }^{17}$}

As well as another black book, this one contains hearings of the accused under torture. Entries consists of description of crime, type of questioning and imposed punishment.

\begin{tabular}{|l|l|l|l|l|}
\hline $\begin{array}{l}\text { Criminal } \\
\text { offence }\end{array}$ & $\begin{array}{l}\text { Type of } \\
\text { record }\end{array}$ & No. & Date & Punishment \\
\hline adultery & court record & $15 \mathrm{~b}$ & 31.12 .1569 & loss of throat by sword \\
\hline bigamy & court record & $15 \mathrm{~b}$ & 31.12 .1569 & loss of throat by sword \\
\hline adultery & court record & $20 \mathrm{~b}$ & 24.3 .1572 & death for both \\
\hline
\end{tabular}

\footnotetext{
${ }^{16}$ Edition used: VOZÁr, Kódex mestského a banského práva.

${ }^{17}$ Edition used: VERBíK, ŠTARHA, Smolná kniha velkobítešská.
} 


\begin{tabular}{|l|l|l|l|l|}
\hline adultery & court record & $21 b-22 b$ & 29.4 .1574 & death \\
\hline $\begin{array}{l}\text { murder of a } \\
\text { newborn }\end{array}$ & court record & $28 b$ & 1577 & death \\
\hline fornication & court record & $44 a$ & 28.6 .1592 & $\begin{array}{l}\text { M: loss of throat by sword } \\
\text { W: death by drowning }\end{array}$ \\
\hline fornication & court record & $44 a$ & 29.6 .1592 & $\begin{array}{l}\text { M: loss of throat by sword } \\
\text { fornication }\end{array}$ \\
\hline court record & $39 a$ & 8.4 .1604 & death by drowning and branding \\
\hline fornication & court record & $45 b$ & 23.10 .1605 & - \\
\hline fornication & court record & $63 a$ & 4.8 .1615 & - \\
\hline
\end{tabular}

Total number of entries: 116

Number of entries about sexual offences: 11

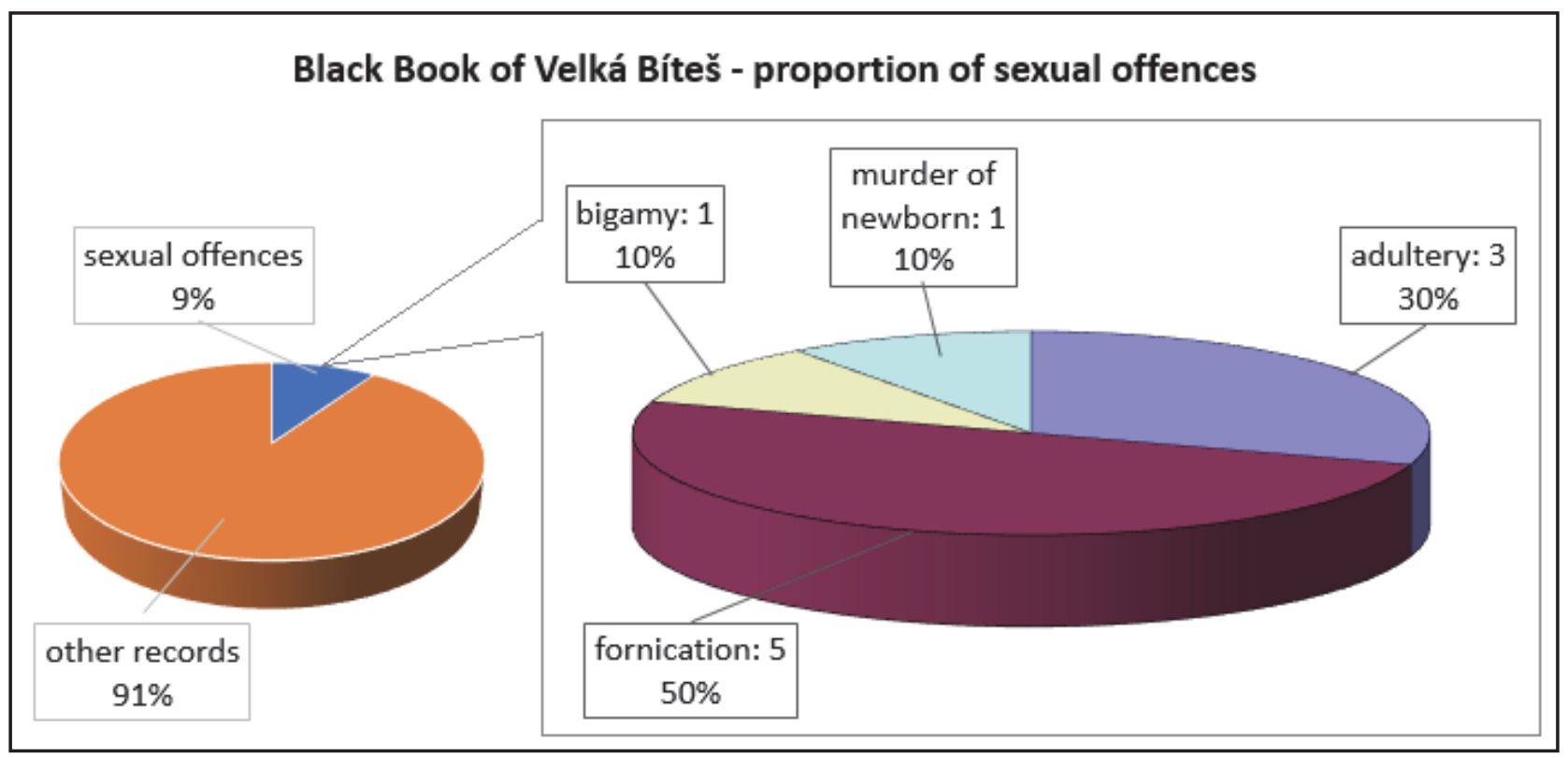


Black Book of Rokycany 1573-1630 ${ }^{18}$

\begin{tabular}{|l|l|l|l|l|}
\hline Criminal offence & Type of record & No. & Date & Punishment \\
\hline fornication & court record & - & 26.2 .1590 & loss of throat by sword \\
\hline fornication etc. & court record & - & 17.7 .1591 & woven onto the wheel and burning \\
\hline adultery etc. & court record & - & 23.7 .1596 & loss of throat by sword \\
\hline incest etc. & court record & - & 28.6 .1599 & loss of throat by sword \\
\hline adultery etc. & court record & - & 28.6 .1599 & death by hanging \\
\hline abortion & court record & - & 7.6 .1599 & whipping and exile \\
\hline rape & court record & - & 15.11 .1606 & - \\
\hline adultery & court record & - & 20.11 .1606 & loss of throat by sword \\
\hline fornication & court record & - & 26.11 .1612 & loss of throat by sword - remission? \\
\hline
\end{tabular}

Total number of entries: 46

Number of entries about sexual offences: 9

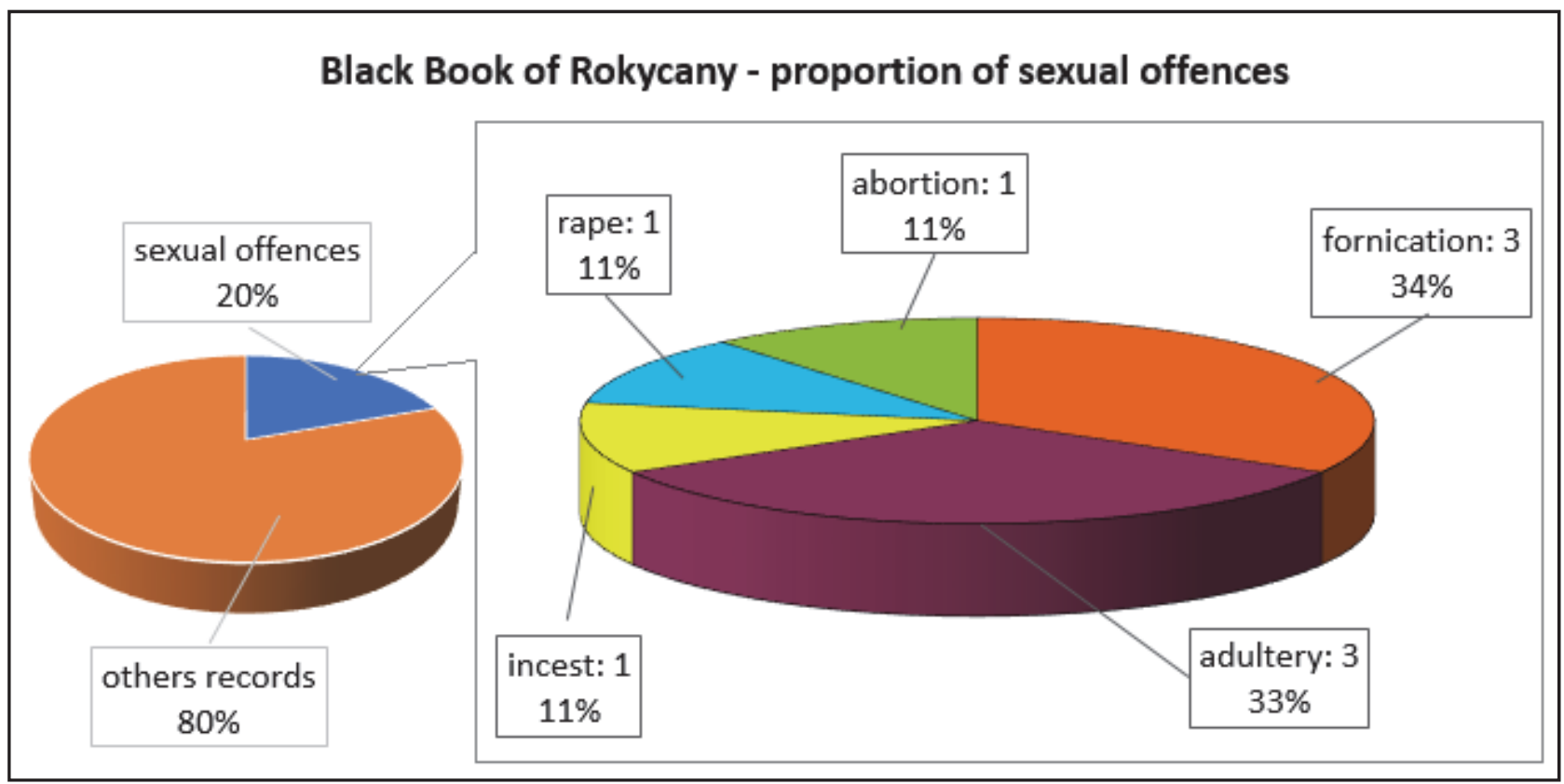

${ }^{18}$ Edition used: CIRONIS, Kniha černá. 


\section{Town Laws of the Kingdom of Bohemia and Margraviate of Moravia $1579^{19}$}

This law book, also known as Koldín's code, is a codification of town law for Bohemia and slightly later also for Moravia and Silesia. It represents an effectual example of younger legal papers. Some provisions are obligatory, others left the decision on the punishment to the judges in the relevant city court.

\begin{tabular}{|c|c|c|c|c|}
\hline $\begin{array}{l}\text { Criminal } \\
\text { offence }\end{array}$ & $\begin{array}{l}\text { Type of } \\
\text { record }\end{array}$ & No. & Date & Punishment \\
\hline adultery & Normative & M.XXIX. & - & loss of throat \\
\hline fornication & Normative & M.XXX.I. & - & whipping and exile from the town \\
\hline rape & Normative & M.XXX.II. & - & - \\
\hline rape & Normative & M.XXXI.I. & - & loss of throat by sword \\
\hline rape of prostitute & Normative & M.XXXI.I. & - & woven onto the wheel \\
\hline help with rape & Normative & M.XXXI.II. & - & same as main perpetrator \\
\hline rape & Normative & M.XXXII.-III. & - & - \\
\hline child abuse & Normative & M.XXXIV. & - & $\begin{array}{l}\text { woven onto the wheel or death by } \\
\text { sword }\end{array}$ \\
\hline rape & Normative & M.XXXVI. & - & marriage or prison \\
\hline adultery & Normative & M.XXXIX & - & husband or father can kill both \\
\hline bigamy & Normative & M.XL. & - & $\begin{array}{l}\text { M: loss of throat by sword } \\
\text { W: burial alive }\end{array}$ \\
\hline pregnancy & Normative & M.XLIII. & - & marriage \\
\hline incest & Normative & N.I. & - & death penalty \\
\hline soliciting & Normative & N.II. & - & death penalty \\
\hline $\begin{array}{l}\text { murder of a } \\
\text { newborn }\end{array}$ & Normative & N.XXXV.III. & - & - \\
\hline abortion & Normative & N.XXXIV. & - & - \\
\hline
\end{tabular}

${ }^{19}$ Edition used: Karel MALÝ, Práva městská. 


\section{Black Book of Lipník 1594-162720}

\begin{tabular}{|c|c|c|c|c|}
\hline $\begin{array}{l}\text { Criminal } \\
\text { offence }\end{array}$ & $\begin{array}{l}\text { Type of } \\
\text { record }\end{array}$ & No. & Date & Punishment \\
\hline fornication etc. & court record & 8 & 22.1.1601 & loss of throat by sword - remission \\
\hline fornication & court record & 10 & 16.9 .1615 & - \\
\hline murder of a newborn & court record & 16 & 17.5.1620 & - \\
\hline fornication etc. & court record & 19 & 24.1.1612 & loss of throat by sword \\
\hline fornication & court record & 20 & 2.5 .1612 & death by wheel \\
\hline fornication & court record & 21 & 9.5.1621 & loss of throat by sword \\
\hline abortion & court record & 24 & 12.2.1615 & brand burning, whipping at the pillory \\
\hline murder of a newborn & court record & 25 & 8.3 .1623 & - \\
\hline adultery & court record & 33 & 17.5.1624 & $\begin{array}{l}\text { loss of throat by sword, changed to } \\
\text { burning a brand, whipping by broom } \\
\text { and exile from the town }\end{array}$ \\
\hline $\begin{array}{l}\text { fornication and abor- } \\
\text { tion }\end{array}$ & court record & 37 & 8.12 .1615 & death by drowning \\
\hline $\begin{array}{l}\text { fornication and murder } \\
\text { of a newborn }\end{array}$ & court record & 45 & - & - \\
\hline
\end{tabular}

Total number of entries: 50

Number of entries about sexual offences: 11

${ }^{20}$ Edition used: MARADA, Smolná kniha města Lipníka. 


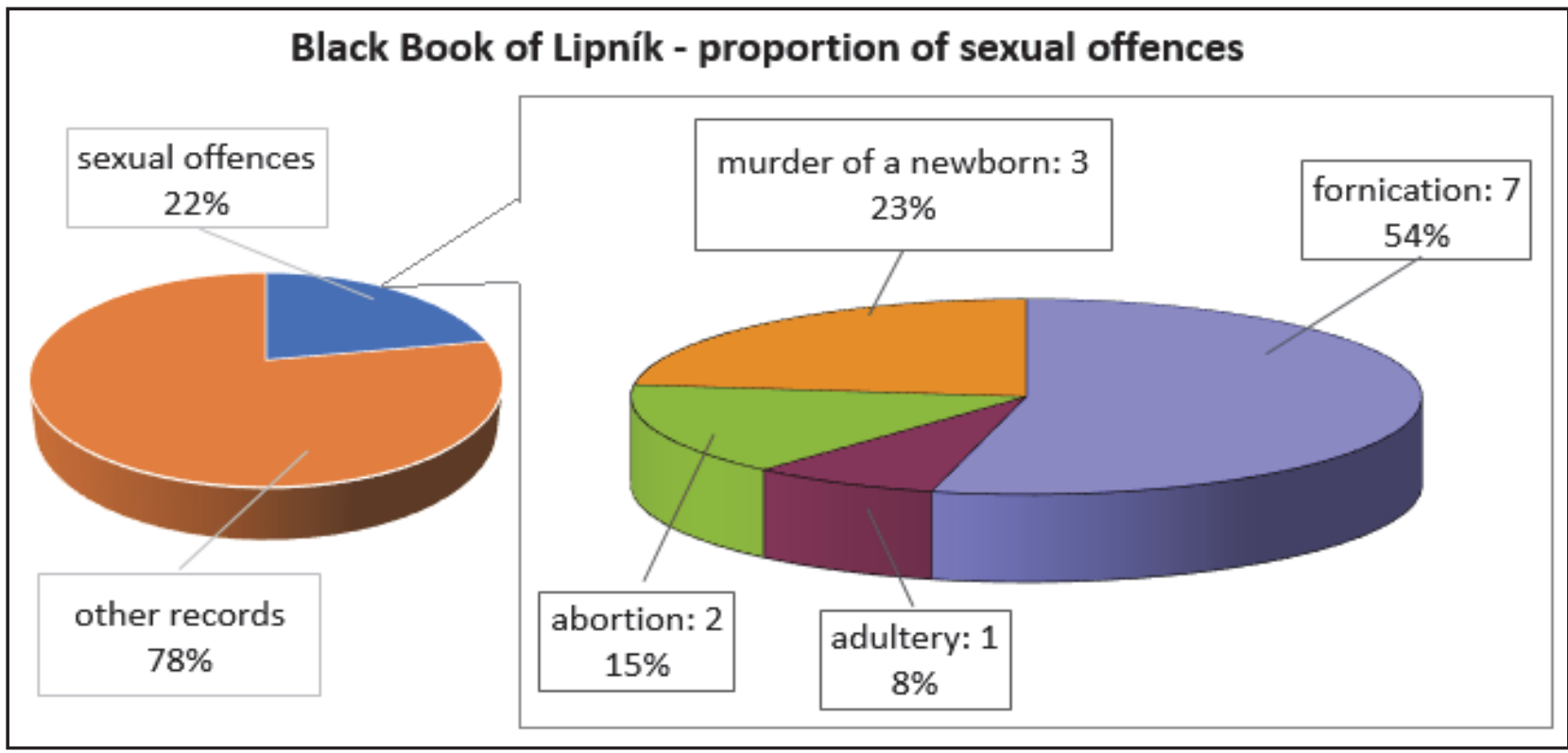

\section{Black Book of Smidary 1631-176921}

\begin{tabular}{|l|l|l|l|l|}
\hline $\begin{array}{l}\text { Criminal } \\
\text { offence }\end{array}$ & $\begin{array}{l}\text { Type of } \\
\text { record }\end{array}$ & No. & Date & Punishment \\
\hline fornication & court record & - & 26.7 .1636 & W: whipping and exile from the town \\
\hline abortion & court record & - & 21.4 .1750 & set in shackles \\
\hline
\end{tabular}

Total number of entries: 34

Number of entries about sexual offences: 2

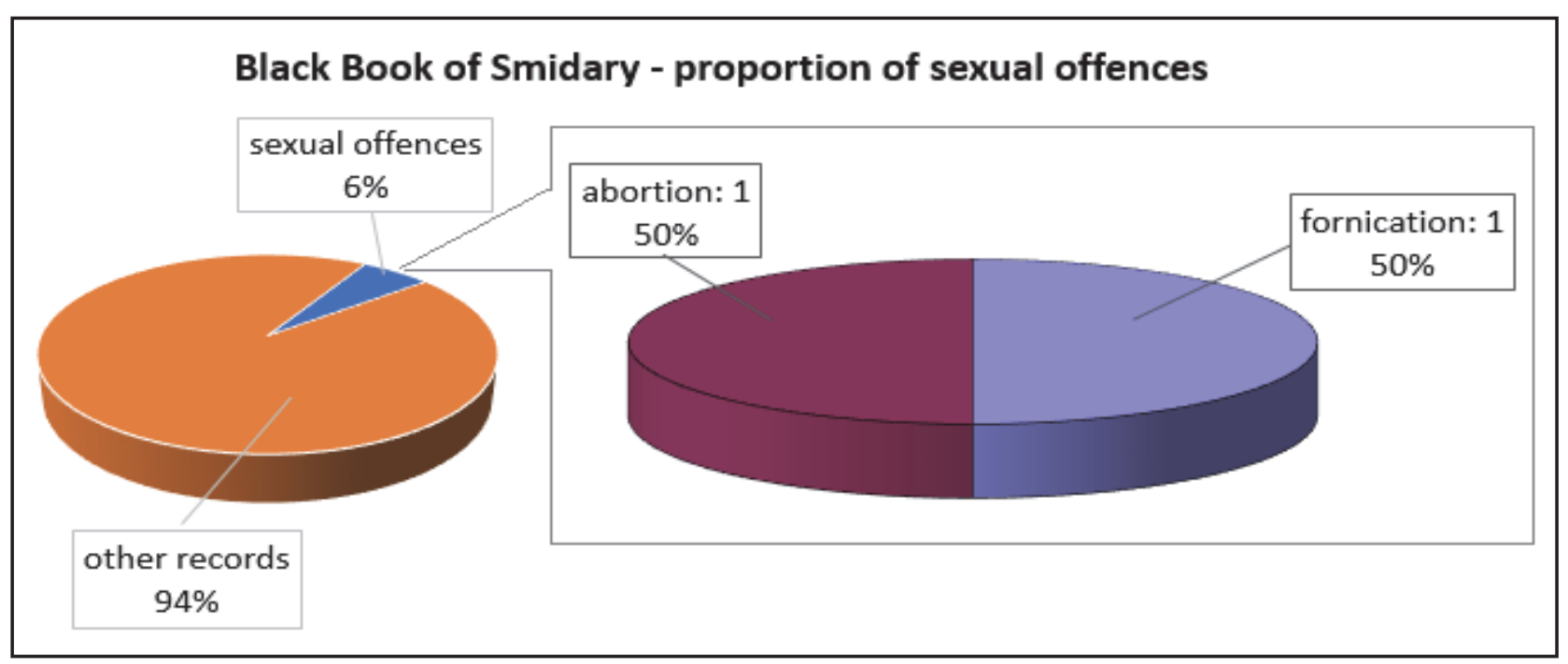

${ }^{21}$ Edition used: LÁNY, Kniha černá jinak smolná města Smidar. 
In the end, it is necessary to highlight and summarize some facts. The age of feudalism knew quite many sexual offences, but their range and variety depended on the proportions of the city, it's size and focus, which means the number of sexual offences rises significantly in cities where more men are present, for example mining cities. Among the most common moral offences were adultery, fornication and rape, related offences, abortion and murder of a newborn. Moral offences were often committed along with other types of crime, possibly combined with each other, so much more severe punishments were often imposed. In comparing the cities, the observance of uniform procedural principles and similar types of punishment are obvious, but within a single city, penalties in very similar cases are very different. This phenomenon is related to changes in the composition of the court, and perhaps also to the circumstances of each particular case. This means that the principle of justice was expressed, at least to the extent that it was possible in the given period, but not necessarily in an objective manner.

Another aspect that is worth mentioning is the fact that this group of crimes is a latent one and, just as at present, the cases reported and solved were only a fraction of their actual number. It follows that their representation in society in relation to other types of crime was most likely much higher than it appears from the records. Also, the overall spectrum of crimes in the given period that were considered criminal or threats to society is interesting. Some of them are also punishable today, although today the offenders would no longer be subjected to the death penalty or another severe, physical punishment. On the other hand, some, such as homosexuality or fornication and adultery, are no longer perceived as crimes, and it is interesting to follow the development of their understanding in society.

\section{Korrespondenz:}

MMag. Alica Kř́ÁPKOVÁ

Veveř́ 70, 61180 Brno

210734@mail.muni.cz

ORCID-Nr. 0000-0001-7764-1496

\begin{abstract}
Abkürzungen:
Siehe das allgemeine Abkürzungsverzeichnis: [http://www.rechtsgeschichte.at/files/abk.pdf]
\end{abstract}




\section{Literatur:}

Marie BISINGEROVÁ, Zdeněk BISINGER, Kutnohorský manuál práva útrpného. Smolná kniha 1521-1571 (Kutná Hora 1987) 17-18.

Marie BlÁHOvÁ, Karel HrdinA, Kosmova kronika česká (Praha 1975).

Petr CIRONIS, Kniha černá nebo smolná královského svobodného města Rokycan z let 1573 - 1630: s př́lohou pozdějších čarodějnických procesů (Rokycany 2000).

Jindřich Francek, Zločin a trest v českých dějinách (Praha 1999).

Jindřich FRANCEK, Velké dějiny zemí Koruny české. Zločinnost a bezpráví (Praha 2011).

Barbora KocÁNOVÁ et al., Městská kniha Litoměřic 1341-1562 v kontex-tu písemností městské kanceláře (Ústí nad Labem 2006).

Rudolf KUCHAR, Žilinská právna kniha. Preklad Magdeburského práva, zápisy právnych úkonov žilinských meštanov (Bratislava 2009).

Miriam LAClavíkovÁ, Andrea Švecová, Pramene práva na území Slovenska. I. Od najstarších čias do roku 1790 (Trnava 2007).
Emil Pavel LÁNY, Kniha černá jinak smolná města Smidar 1631-1769 (Liberec 1948).

Karel MALÝ, Práva městská Království českého: edice s komentářem (Praha 2013).

Miroslav MARADA, Smolná kniha města Lipníka (Přerov 1994).

Mária PAPSONOVÁ, Sasko-magdeburské právo na Slovensku. Krajinské právo v Žilinskej knihe (Žilina 2014).

Vladimír SPÁČIL, Nejstarší městská kniha olomoucká (Liber actum notabilium) z let 1343-1420 (Olomouc 1982).

Vladimír SPÁČIL, Libuše SPÁČILOVÁ, Míšeňská právní kniha. Historický kontext, jazykový rozbor, edice (Olomouc 2010).

Antonín VERBÍK, Ivan ŠTARHA, Smolná kniha velkobítešská 1556-1636 (Brno 1973).

Ladislav VoJÁČEK, Karel SCHELlE, Vilém KNOLL, České právní dějiny (Plzeň 2010).

Jozef VOZÁR, Kódex mestského a banského práva Banskej Štiavnice: znenie podla skvostne vyhotoveného rukopisu z roku 1572 (Košice 2002). 